\title{
On the Jurisdiction of Foreign Divorce Cases in China
}

\author{
Xueer Han ${ }^{1}$, Hanyue Xue ${ }^{2}$, Yiou Chen ${ }^{1}$, Xuelin Liu ${ }^{1} \&$ Yitao Liu ${ }^{1}$ \\ ${ }^{1}$ School of Inner Mongolia University of Technology, Hohhot, China \\ Correspondence: Xueer Han, School of Inner Mongolia University of Technology, Hohhot 010000, China. \\ E-mail: 943946679@qq.com
}

Received: December 1, 2021

Accepted: December 20, $2021 \quad$ Online Published: December 23, 2021

doi:10.20849/ajsss.v6i5.966

URL: https://doi.org/10.20849/ajsss.v6i5.966

\begin{abstract}
This article takes China's jurisdiction over foreign-related divorce cases as an entry point, and systematically expounds the provisions of China's foreign-related divorce jurisdiction. According to my country's regulations, my country's jurisdiction over a foreign-related divorce is vertically divided into direct jurisdiction and indirect jurisdiction, and horizontally divided into personal Jurisdiction, territorial jurisdiction, exclusive jurisdiction, and jurisdiction by agreement. In my country's Civil Procedure Law and related judicial interpretations, the domicile of the "plaintiff is the defendant" and the location of the plaintiff under certain circumstances is the main focus. The general solution path of the case; At the same time, my country's regulations on foreign-related divorce cases still have shortcomings, and there are still many areas that need to be improved. This article analyzes the shortcomings and the areas to be improved.
\end{abstract}

Keywords: foreign-related divorce, divorce jurisdiction; divorce proceedings

\section{Introduction}

Foreign-related divorce refers to a divorce case where the interests of one or both spouses involve foreign factors, including a couple who are married in China and settled abroad, and are Chinese citizens, one is living abroad, and the other is living in the country. The two parties who are Chinese citizens are abroad but have not settled down, a divorce case filed by a people's court, a domestic intermediate people's court ruled that a foreign court's divorce judgment is not recognized, etc. (https://wenku.so.com/d/9efca3789fc104b8e84d2db06fb5140c)

Foreign-related jurisdiction is divided into direct jurisdiction and indirect jurisdiction. Direct jurisdiction refers to the jurisdiction of a national court to decide whether it has the right to try the event by the relevant national laws when handling the event. In addition, indirect jurisdiction means that when a country's court recognizes and enforces a foreign court's judgment, the foreign court's exercise of jurisdiction is properly examined. The former examines whether the domestic courts have jurisdiction over divorce proceedings, and the latter examines whether foreign courts have jurisdiction over the divorce proceedings (https://www.docin.com/p-1127950630.html). These countries constitute a jurisdiction system for a country's diplomatic divorce cases. The standards for the establishment of foreign-related jurisdiction in each country are combined with their specific national conditions. Therefore, all countries have various standards for establishing jurisdiction over foreign-related divorce cases. All the same.

\section{Principles of Basis for the Jurisdiction of Foreign-Related Divorce}

The administrative jurisdiction of foreign-related civil litigation refers to the administrative jurisdiction of the Supreme People's Court of a country for first-instance or second-instance foreign-related civil cases and the administrative division of labor of the courts at all levels and above to accept first-instance or second-instance foreign-related civil cases. The establishment of the administrative jurisdiction of foreign-related civil litigation directly affects the protection and maintenance of the sovereignty of the entire country. Therefore, all countries in the world are very concerned about the issue of administrative jurisdiction. In addition, according to factors such as the connection between the jurisdictions of foreign-related civil litigation that need to be emphasized by various countries in the world, different principles for determining the jurisdiction of foreign-related civil litigation have been formed:

\subsection{Principle of Personal Jurisdiction}

In other words, under certain circumstances, the parties of one party have specific nationality. No matter they are 
plaintiffs or victims, and wherever they live or go, the Supreme Prosecutor or the court in the place of nationality should have jurisdiction over such civil cases. The principle of personal administrative supervision and jurisdiction is closely centered on the vital interests of the country and social citizens. Especially in criminal cases involving the vital interests of citizens such as divorce, the principle of personal administrative supervision and jurisdiction is more inclined to protect the vital interests of citizens according to law. The principle closely revolves around the vital interests of the state and citizens, especially in cases involving the personal interests of citizens such as divorce, the personal principle tends to protect the interests of its citizens.

\subsection{Principle of Territorial Jurisdiction}

The basic principle of vested jurisdiction is that in foreign-related divorce civil cases, if the parties ' housing, property, the subject matter of litigation, production disputes, and other legal relations are not clear or contradictory to such legal disputes, as long as there is a major influencing factor that may exist in one country or may occur in another country, the place can obtain vested and jurisdiction over such cases. In the principle of territorial jurisdiction, the defendant's residence is usually used as the basis for the court to exercise jurisdiction. It is a very common way to determine the jurisdiction of divorce cases by the residence of the parties, taking into account the relationship between the divorce cases of the parties and the courts under their jurisdiction based on the residence. However, the criteria for determining the residence of citizens in various countries vary according to their specific national conditions. Sometimes there will be situations where a person has multiple residences, which will result in situations where multiple courts have jurisdiction or are not willing to take over cases. In this regard, the Hague Conference on Private International Law has clarified the definition of habitual residence and improved this situation.

\subsection{Exclusive Jurisdiction Principle}

If a civil case involves a country's public interest or other major interests, the country enjoys the exclusive jurisdiction of the case, and other countries and regions cannot and have no right to challenge or interfere with the jurisdiction of the case. Because it involves the vital interests of a country, divorce cases judged according to the principle of exclusive jurisdiction often involve the issue of conflict of jurisdiction. When the jurisdiction of foreign-related divorce cases between countries conflicts, the divorce case cannot be well solved. Many countries have been aware of the drawbacks brought by the conflict of jurisdiction in divorce cases. Therefore, when applying the exclusive jurisdiction principle, all countries try to adopt the way of comity or recognition of the judgment to avoid the negative impact brought by the conflict of jurisdiction in divorce cases.

\subsection{Agreement Jurisdiction Principle}

That is, the parties determine the jurisdiction of the court according to the basis of autonomy. Different from the above three principles, the principle of agreement jurisdiction is the embodiment of the private rights of both husband and wife, reflecting the flexibility of the provisions of jurisdiction and respect for the autonomy of both husband and wife. Although the principle of contractual jurisdiction fully respects the parties' agreement reached based on the autonomy of will, the parties in the principle of contractual jurisdiction are not absolute autonomy of will, because foreign-related divorce cases are not only related to the personal interests and property interests of both parties, but also the jurisdiction of various countries and social public order. Therefore, when the parties agree to jurisdiction in the agreement, they should strictly abide by social public order and whether the court has jurisdiction.

\section{The Legislative Development of the Jurisdiction of Foreign-Related Divorce}

In the 1950s and 1960s, my country implemented unilateral jurisdictional regulations. As long as foreign-related divorce cases occurred in my country, they were under the jurisdiction of Chinese courts, and they believed that "should" be under the jurisdiction of Chinese courts (Ma, Wenwen, 2012).

Later, with the continuous development of reform and opening up and China's foreign relations, my country's legislation has also further developed. In the 1980s and 1990s, China began to gradually recognize the jurisdiction of foreign courts in foreign-related divorce cases, and the wording also changed from "should" "Changed into "Yes."

At present, my country's jurisdictional provisions on foreign-related divorce are in the current "Civil Procedure Law" and its related judicial interpretations, which mainly focus on the place where the "plaintiff is the defendant" and the place of the plaintiff under certain circumstances. 


\section{The Relevant Provisions of the "Civil Procedure Law" Concerning the Content of Foreign-Related Divorce Jurisdiction and Its Judicial Interpretation}

Article 22 of the Civil Procedure Law stipulates the basic jurisdictional principle of "the plaintiff is the defendant", and the jurisdiction is determined based on the plaintiff in the defendant's place of residence (regular residence). Article 3 of the Civil Procedure Law has made special legal provisions on the scope of patent jurisdiction, that is to say, the people's court of the legal domicile of the patent plaintiff (usually the residence of the defendant) is directly responsible for this special jurisdiction. Circumstances, the first paragraph stipulates that patent victims who are not legally residing in Xinhua China at all can also initiate patent civil lawsuits that have nothing to do with other citizenships. Undoubtedly, foreign-related civil divorce litigation cases are a kind of litigation that belongs to the qualifications for the conclusion of a divorce contract. Other relevant provisions of the Civil Procedure Law. Articles 13 and 14 of the judicial interpretation respectively clearly stipulate that the parties to the marriage of both spouses may be foreign overseas Chinese residing abroad at the same time. Civil litigation for divorce in other countries must be based on the place where the marriage agreement of the other country is concluded or the place where the marriage with nationality belongs to. If the foreign people's court has the authority to be responsible for its jurisdiction and ruled not to be accepted in court, both spouses can simultaneously file a complaint. When the people's court filed an application and simultaneously filed a civil lawsuit for divorce in other countries, the other parties have the right to be simultaneously responsible for its jurisdiction. The people's court has the right to be responsible for its jurisdiction. It can be seen that the main purpose of Article 13 and Article 14 is to use the common resident nationality status of the divorced parties of the spouse as the legal basis for determining their jurisdiction. The purpose is to provide divorce judicial remedies for foreign nationals by the law, and to protect other foreign nationals. The legal right of persons to participate in the civil litigation of divorce in their country. Article 15 clearly stipulates that the divorce parties of both spouses are both of the same person or citizens of mainland China, and when one party has a long-term or residency in China, and the other party has a long-term or residency abroad, no matter what special circumstances apply to the people's court or file Chinese citizenship. In the civil litigation of divorce, the people's court can have the right to execute the divorce case in the first instance.

\section{The General Approach to the Settlement of Conflicts of a Foreign Jurisdiction}

\subsection{Expansion of the Scope of Application of the Jurisdiction of the Agreement}

Since the jurisdiction by agreement is determined based on the consensus of the parties, to a certain extent, the principle of jurisdiction by agreement can reduce the trust or dissatisfaction of the parties to the jurisdiction of the court, and can avoid the disputes and conflicts between the parties due to the jurisdiction of the court.

\subsection{Inconvenient Application of the Court Principle}

The principle of court inconvenience means that in a foreign-related divorce case if the first court found that the divorce case should not be under the jurisdiction of this court during the review process, and it would harm the interests of the parties if there are other jurisdictions at this time If the court can hear the case, it can be transferred to the appropriate court for trial. This not only protects the rights and interests of the parties but also facilitates the trial of the case.

\subsection{Sign Contracts With Other Countries to Strengthen Exchanges}

In the process of following various jurisdictional principles, sometimes the courts of various countries will inevitably have conflicts in the jurisdiction of divorce cases. To protect the rights of the parties and the orderly process of the various courts, various countries can actively develop exchanges and sign international agreements. Treaties determine the application of jurisdiction, to solve the problem of jurisdictional conflicts between countries at the root.

\section{Insufficiency of My Country's Foreign-Related Divorce Regulations}

\subsection{Lack of Specific Provisions In-laws and Regulations}

In my country's "Civil Procedure Law", there are no provisions on the specific principles governing foreign-related divorce, only the relevant judicial interpretations mention them, although the Supreme People's Court's judicial interpretation, the Supreme People's Court alone or in conjunction with other departments' notice The publication and the Supreme People's Court's approval of individual cases have played a role in checking for omissions, no specific provisions have been made from the foreign-related divorce itself, and there is still a lack of specific guidance, and there is still a lack of certainty for the interests of the parties. Protective effects. 


\subsection{Lack of Specific Principled Guidance}

The principle of jurisdiction for foreign-related divorce in China is neither a complete personal principle nor a complete territorial principle. It is principled and lacks specific rules for maneuverability.

\subsection{The Scope of the Party's Provisions Is Limited}

The most important consideration in the legislation is the issue of divorce between Chinese citizens and mainland Chinese citizens; here we have considered more divorce between Chinese overseas Chinese and foreigners, and for a divorce between Chinese and other foreigners only It can be seen as a single person approving (https://wenku.so.com/d/9efca3789fc104b8e84d2db06fb5140c). For Chinese citizens who emigrate (including non-Chinese citizens), they can only exercise their rights when special circumstances occur in China. Such special circumstances are unfair and have no potential to protect and maintain the safety and well-being of everyone. It is not conducive to maintaining and protecting the safety and vital interests of all Chinese citizens. It has not been able to clearly determine whether the Chinese courts have jurisdiction over foreign-related divorce between foreigners (different from stateless persons), and between foreigners and other stateless persons.

\section{Perfection of Divorce Jurisdiction System Concerning Foreign Affairs}

\subsection{Clarify the Laws and Regulations Governing Foreign-Related Divorce Cases}

Because China's current regulations on foreign-related divorce jurisdiction are embodied in the judicial interpretations of the Civil Procedure Law and other judicial interpretations and explanations, but not in the laws and regulations, the relevant provisions can be based on my country's national conditions. And learn from the relevant laws and regulations of the country that have been more appropriate in practice. Specifying the jurisdiction of foreign-related divorce cases in my country's laws and regulations will help judicial staff have laws to follow in handling relevant cases, avoid unnecessary hesitation and hesitation in practical procedures, and improve work efficiency.

\subsection{Appropriately Expand the Scope of Applicable Subjects}

First, expand the scope of application of personal jurisdiction. Even if one of the spouses is an overseas Chinese in my country and the other is a foreigner with foreign nationality, the overseas Chinese should promptly accept the case when seeking judicial relief from my country to protect the interests of the parties in my country. Secondly, for foreigners who have lived in my country for a long time, their living habits and vital interests are inseparable from the environment of our country. When they seek judicial relief from our country when handling a divorce, they should protect their legal rights and interests by our laws and regulations. Finally, foreign couples with foreign nationalities who are both involved in concluding a marriage in our country are allowed to file a lawsuit to dissolve their marriage relationship at the place of marriage registration. The marriage of foreign couples in our country demonstrates to a certain extent their recognition of our country's legal environment. It should be given the right to sue for divorce.

\subsection{The Principle of the Reasonable Use of Inconvenient Courts}

As mentioned above, the inconvenience principle can avoid conflicts of jurisdiction between countries to a certain extent. The judicial interpretation of my country's Civil Procedure Law has also stipulated the inconvenience principle. However, the problem to be noted is that While applying the principle of inconvenience to the courts, it is also necessary to fully protect the interests of the disadvantaged party in the marriage, minor children, and the elderly.

\subsection{Specify Where the Main Property Belongs}

Foreign-related divorce cases involve the division of the common property of the spouse. Taking into account the differences in the ownership of the spouses and the location of the property, in order to facilitate the use and disposal of the property by the parties after the division of the property, the principle of territoriality should also be applied to the main property. Fully protecting the private property of both parties will also help the parties enjoy adequate legal protection based on the location of the divided property, and facilitate the parties to exercise their legal rights.

\section{References}

Ma, W.-W. (2012). Research on the Legal Issues of Divorce Concerning Foreign Affairs in my country. Master Thesis, Anhui University, China, pp. 1-53.

Retrieved from https://wenku.so.com/d/9efca3789fc104b8e84d2db06fb5140c

Retrieved from https://wenku.so.com/d/9efca3789fc104b8e84d2db06fb5140c 
Retrieved from https://www.docin.com/p-1127950630.html

\section{Copyrights}

Copyright for this article is retained by the author(s), with first publication rights granted to the journal.

This is an open-access article distributed under the terms and conditions of the Creative Commons Attribution license (http://creativecommons.org/licenses/by/4.0/). 